\title{
Source material for breeding soft winter wheat in the forest- steppe of the Middle Volga region
}

\author{
Nadezhda Zakharova*, Nikolai Zakharov \\ P.A. Stolypin Ulyanovsk State Agrarian University, Ulyanovsk, Russia
}

\begin{abstract}
The source material is the initial link of the selection process of any crop. A careful study of it in specific environmental conditions largely determines the effectiveness of breeding activities. The paper presents the results of a study of 102 cultivars of soft winter wheat of various ecological and geographical origin in terms of the yield, winter hardiness, the plant height, the duration of the growing season, the resistance to the frit fly. The sources of individual and a complex of economically valuable indicators were identified and recommended as the source material for breeding use in the forest-steppe conditions of the Middle Volga region. In the winter wheat selection for high winter hardiness, the varieties Omskaya 6, Bagrationovskaya, Novosibirskaya 32, Novosibirskaya 51, Biyskaya Ozimaya, Filatovka, Kulundinka, Poema (Russia), Banga (Latvia), Emoile (Bulgaria), Myropol, Mykolayvka, Dashenka, Kalyanova, Lytavinka, Vinnychanka, Manzheliya, Khersonska bezostaya (Ukraine), Xiao Yan 107, Zhong Pin 1535 (China) are of great interest. Highly productive varieties are Victoria 95, Poema, Biyskaya Ozimaya (Russia), Zamozhnist, Kalyanova, Yasnogorka (Ukraine). Varieties Vdachna, Shestopalivka, Myropol (Ukraine), Svilena, Emoile (Bulgaria), KS 96 WGRC 37, KS 96 WGRC 40, Pacer (USA), Kitami 46 (Japan) XiaoYan 6, Ji Mai 30, Ji Mai 36 (China) are characterized by early ripeness. Short-stalked wheat varieties are Cameo (Russia), Ninka (Ukraine), Ji Mai 18 (China), Kitami 35 (Japan). Highly resistant varieties to the frit fly are Donskaya 50, Dominanta, Poema (Russia), Yasnogorka (Ukraine), Orienta, KS 96 WGRC34, KS 96 WGRC40 (USA), Xiao Yan 7, Zhong Pin 1507, Zhong Pin 1535 (China), Kitami 35 (Japan). Reliable correlations between winter hardiness and productivity, winter hardiness and plant height, plant height and productivity of soft winter wheat were established, which is of practical importance both for crop breeding and for its production use.
\end{abstract}

\section{Introduction}

Soft winter wheat is one of the leading crops in agriculture in the Ulyanovsk region, which is located in the forest-steppe zone of the Middle Volga region. In some years $(2009,2011,2015,2019,2020)$, its sown area exceeded 250 thousand hectares, which is more than $25.0 \%$ of the total sown area of agricultural crops [1]. The varietal composition of soft winter wheat cultivated in the region does not completely provide the desired level of grain yield of this crop and its stability, which is primarily associated with insufficient resistance to unfavorable environmental factors.

In this regard, the demand for new varieties with a complex of valuable indicators and capable of producing high yields in variable environmental conditions is constantly increasing [2]. Well-studied initial material is required to create new varieties.

At the same time, special attention should be paid to the expansion of the genetic diversity of crossed forms, which will make it possible to increase the productivity of breeding achievements significantly, to overcome the vulnerability of agricultural crops to biotic stresses and expand their adaptation to changing environmental conditions [3-5].

The purpose of the conducted studies was to investigate the range of soft winter wheat of various ecological and geographical origin by a set of indicators and to highlight the sources of economically valuable traits and properties as the source material for breeding soft winter wheat in the forest-steppe conditions of the Middle Volga region.

\section{Materials and methods}

Two sets of soft winter wheat cultivars (51 pcs. each) of various ecological and geographical origin from the collection of the N.I. Vavilov All-Russian Institute of Plant Genetic Resources served as the material for the study. The plot area is $0.9 \mathrm{~m}^{2}$ without replication. The predecessor is bare fallow. Sowing was carried out at the time recommended for the studied crop - from August 25 to September 5. The winter hardiness assessment, plant height, phenological phases of growth and development of soft winter wheat and yield registration

* Corresponding author: ugsha@yandex.ru 
were carried out according to the techniques recommended for variety trials [6, 7]. The variety Volzhskaya $\mathrm{K}$ was adopted as the standard one in the variety testing of soft winter wheat in the Ulyanovsk region during the years of studies.

\section{Results and Discussion}

The creation of a variety with the highest possible yield level is the ultimate goal of every breeder's work. This indicator serves as the main criterion for the effectiveness of any breeding program. At the same time, selection for the yield increase is one of the most difficult tasks, which is associated with the extraordinary complexity and complication of this indicator $[8,9]$.

In all the years of studies, the level of productivity of soft winter wheat was influenced by stress factors of the winter period. In 2012 and 2013 arid conditions in the spring-summer growing season of the crop also played a negative role in the yield formation. Severe damage to winter wheat crops by the frit fly (Oscinella frit L.) was observed in 2012, which also negatively affected its yield. In various environmental conditions, the intervarietal yield differentiation was noticed among wheats from different countries of the world (Table 1).
Winter hardiness is one of the most important indicators for winter crops [10]. In case of favorable overwintering, they give a higher yield compared to spring crops. In connection with the tendency of climate warming, more and more often the factors causing damage and death of winter crops during winter in the Middle Volga region are the so-called "effects of mild winters" damping-off (probability is 40\%), thaws, sudden temperature changes, ice crust (probability is 13\%) [11]. In 2011, the ice crust had a damaging effect on winter wheat plants, and in 2012 and 2013 - damping off occurred.

Among the studied range of wheat of the world collection in the forest-steppe conditions of the Middle Volga region, Hungarian wheats were characterized by low winter hardiness (1.0-2.0 points) in both years of studies, medium and increased winter hardiness (3.0-4.0 points) showed varieties of Bulgaria, increased and high (4.0-5.0 points) - Russian wheats bred in Siberia (Table $1)$.

Winter hardiness differentiation was observed among wheat cultivars from Ukraine, Germany, Serbia, China, USA, Japan, Estonia, Latvia, and the North Caucasian region of Russia.

Table 1. Economic and biological indicators of soft winter wheat cultivars of various ecological and geographical origin (average value / limits)

\begin{tabular}{|c|c|c|c|c|c|c|c|c|}
\hline \multirow[t]{3}{*}{ Wheat origin } & \multicolumn{2}{|c|}{$\begin{array}{l}\text { Yield, } \\
\mathrm{g} / \mathrm{m}^{2}\end{array}$} & \multicolumn{2}{|c|}{$\begin{array}{c}\text { Winter hardiness, } \\
\text { point }\end{array}$} & \multicolumn{2}{|c|}{ Plant height, $\mathrm{cm}$} & \multicolumn{2}{|c|}{ Ear formation date } \\
\hline & \multicolumn{8}{|c|}{ First set of cultivars } \\
\hline & 2011 & 2012 & 2011 & 2012 & 2011 & 2012 & 2011 & 2012 \\
\hline Volzhskaya K & 630 & 367 & 4.5 & 5.0 & 104 & 71 & $5 \mathrm{VI}$ & $2 \mathrm{VI}$ \\
\hline Ukraine & $\frac{383}{40-976}$ & $\frac{248}{78-498}$ & $\frac{3.0}{1.0-5.0}$ & $\frac{3.9}{1.0-5.0}$ & $\frac{73}{63-94}$ & $\frac{48}{36-58}$ & $\frac{4 \mathrm{VI}}{29 \mathrm{~V}-11 \mathrm{VI}}$ & $\frac{29 \mathrm{~V}}{23 \mathrm{~V}-3 \mathrm{VI}}$ \\
\hline Germany & $\frac{222}{20-423}$ & $\frac{202}{17 \underline{1-233}}$ & $2 . \frac{3.0}{2-4.0}$ & $2 . \frac{2,8}{5-3.0}$ & $\frac{82}{75-88}$ & $\underline{54}$ & $12 \frac{12 \mathrm{VI}}{\mathrm{VI}-13 \mathrm{VI}}$ & $\frac{9 \mathrm{VI}}{8 \mathrm{VI}-10 \mathrm{VI}}$ \\
\hline Hungary & $2 \frac{41}{22-59}$ & 244 & $\frac{1.5}{1.0-2.0}$ & $\underline{1.5}$ & $\underline{49}$ & 48 & $2 \underline{4 \mathrm{VI}-6 \mathrm{VI}}$ & $2 \mathrm{VI}$ \\
\hline Bulgaria & $27 \frac{469}{6-606}$ & $\frac{200}{153-282}$ & $3 . \underline{3.7}-4.0$ & $3 . \underline{3.3}-4.0$ & $\frac{78}{76-80}$ & $\frac{48}{47-50}$ & $\frac{2 \mathrm{VI}}{1 \mathrm{VI}-4 \mathrm{VI}}$ & $\frac{28 \mathrm{~V}}{24 \mathrm{~V}-30 \mathrm{~V}}$ \\
\hline Serbia & $\frac{251}{40-670}$ & $\stackrel{99}{54-149}$ & $\frac{2.8}{1.0-4.5}$ & $2 . \frac{3.7}{2.0-5.0}$ & $\frac{70}{60-80}$ & $3 \frac{44}{37-53}$ & $6 \mathrm{VI}$ & $\frac{1 \mathrm{VI}}{27 \mathrm{~V}-3 \mathrm{VI}}$ \\
\hline China & $\frac{219}{13-535}$ & $\frac{176}{22-458}$ & $\frac{3.4}{1.0-5.0}$ & $\frac{2.8}{1.0-5.0}$ & $\frac{67}{34-85}$ & $3 \frac{48}{30-56}$ & $\frac{2 \mathrm{VI}}{29 \mathrm{~V}-7 \mathrm{VI}}$ & $23 \frac{27 \mathrm{~V}}{\mathrm{~V}-1 \mathrm{VI}}$ \\
\hline $\begin{array}{l}\text { Average in the } \\
\text { experiment }\end{array}$ & 328 & 222 & 3.1 & 3.5 & 72 & 49 & $4 \mathrm{VI}$ & $29 \mathrm{~V}$ \\
\hline & & & Secor & t of cultiv & & & & \\
\hline Wheat origin & 2012 & 2013 & 2012 & 2013 & 2012 & 2013 & 2012 & 2013 \\
\hline Volzhskaya K & 367 & 162 & 5.0 & 5.0 & 71 & 72 & $2 \mathrm{VI}$ & $4 \mathrm{VI}$ \\
\hline $\begin{array}{l}\text { Russia, Northern } \\
\text { Caucasus }\end{array}$ & $\frac{241}{59-358}$ & $\frac{107}{42-172}$ & $\frac{4.7}{4.0-5.0}$ & $\frac{2.7}{2.0-4.0}$ & $3 \frac{45}{33-54}$ & $\frac{53}{43-63}$ & $25 \stackrel{28 \mathrm{~V}}{\mathrm{~V}-3 \mathrm{VI}}$ & $2 \frac{3 \mathrm{VI}}{\mathrm{VI}-5 \mathrm{VI}}$ \\
\hline Russia, Siberia & $\frac{302}{60-505}$ & $\frac{146}{25-264}$ & $\begin{array}{c}4.9 \\
4.0-5.0 \\
\end{array}$ & $4.0-5.7 .0$ & $\underline{65}-98$ & $60 \underline{89}-104$ & $30 \frac{1 \mathrm{VI}}{\mathrm{V}-3 \mathrm{VI}}$ & $\frac{4 \mathrm{VI}}{2 \mathrm{VI}-5 \mathrm{VI}}$ \\
\hline Ukraine & $12 \frac{307}{6-507}$ & $\frac{114}{5-261}$ & $3 . \underline{4.6}$ & $\frac{2.3}{1.0-4.0}$ & $\frac{53}{43-65}$ & $\frac{55}{38-81}$ & $\frac{28 \mathrm{~V}}{24 \mathrm{~V}-31 \mathrm{~V}}$ & $2 \frac{4 \mathrm{VI}}{2 \mathrm{VI}-6 \mathrm{VI}}$ \\
\hline USA & $\frac{171}{71-253}$ & $\underline{50}$ & $2 . \underline{3.6}$ & $\frac{1.8}{1.0-3.0}$ & $\frac{44}{36-53}$ & $\frac{57}{33-78}$ & $\frac{225}{22 \mathrm{~V}-2 \mathrm{VI}}$ & $\frac{3 \mathrm{VI}}{1 \mathrm{VI}-4 \mathrm{VI}}$ \\
\hline Japan & $\frac{179}{87-240}$ & $12 \frac{143}{5-161}$ & $\frac{4.1}{4.0-4.5}$ & $\frac{2.4}{1.0-3.5}$ & $\underline{52}$ & $\frac{72}{65-78}$ & $\frac{29 \mathrm{~V}}{27 \mathrm{~V}-31 \mathrm{~V}}$ & $\frac{3 \mathrm{VI}}{1 \mathrm{VI}-5 \mathrm{VI}}$ \\
\hline $\begin{array}{l}\text { Estonia, } \\
\text { Latvia }\end{array}$ & $\frac{230}{118-322}$ & $\frac{49}{6-91}$ & $3 . \underline{4.0}$ & $\frac{1.7}{1.0-3.5}$ & $\frac{69}{62-75}$ & $\underline{58}$ & $\frac{1 \mathrm{VI}}{26 \mathrm{~V}-4 \mathrm{VI}}$ & $\frac{5 \mathrm{VI}}{4 \mathrm{VI}-6 \mathrm{VI}}$ \\
\hline $\begin{array}{l}\text { Average in the } \\
\text { experiment }\end{array}$ & 239 & 126 & 4.2 & 2.8 & 59 & 66 & $29 \mathrm{~V}$ & $4 \mathrm{VI}$ \\
\hline
\end{tabular}


Due to damage by the ice crust, the average value of overwintering in the experiment in 2011 was 3.1 points. In $32.0 \%$ of wheat, winter hardiness was estimated at 3.0 points, in $32.0 \%$ of cultivars -4.0 points. High winter hardiness of 5.0 points under such conditions was shown by the varieties Omskaya 6 (Russia), Xiao Yan 107 (China), Mykolayvka, Manzheliya (Ukraine). In 2012, for the same set of wheat, most of the cultivars also had overwintering at 3.0 and 4.0 points $(34.0 \%$ and $26.0 \%$ of wheat, respectively) due to slight damping off. The average value of winter hardiness in the experiment in the studied year was 3.5 points. Based on the results of 2 years of studies, wheat cultivars Volzhskaya K, Omskaya 6 (Russia), Banga (Latvia), Emoile (Bulgaria), Myropol, Mykolayvka, Dashenka, Kalyanova, LytavinkaVinnychanka, Manzheliya, Khersonskabezostaya (Ukraine), Xiao Yan 107, Zhong Pin 1535 (China) were characterized by complex resistance to ice crust and damping off (4.0-5.0 points).

In the second set of wheat cultivars, the average value of overwintering according to the experiment of 2012 was 4.2 points (Table 1), which is higher than the
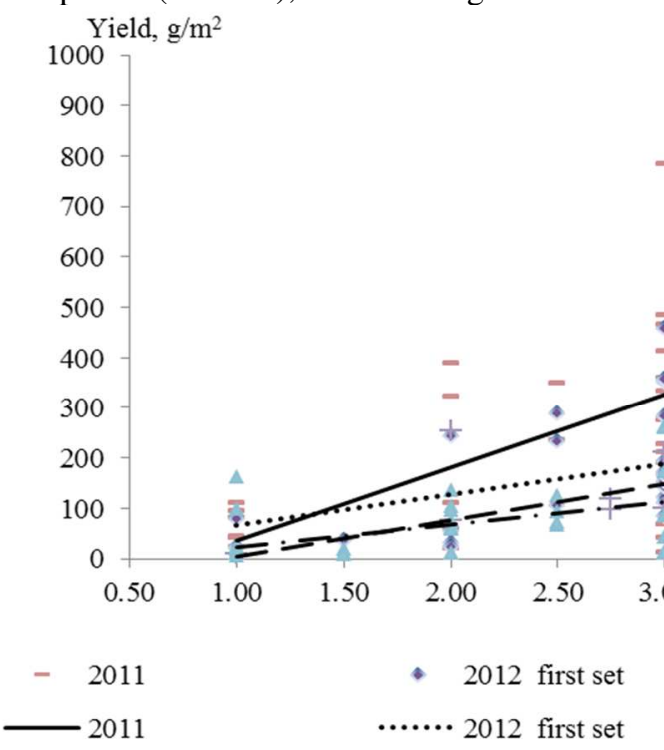

value of the first set ( 3.5 points). The reason for this was the presence of Russian wheat varieties of Siberian selection in the second set with a high level of winter hardiness. The winter hardiness grading of cultivars in 2013 was low due to strong damping off (the average value in the experiment was 2.8 points). In almost $50 \%$ of winter wheat cultivars, winter hardiness was assessed at 2.0-3.0 points. The varieties: Bagrationovskaya, Novosibirskaya 32, Novosibirskaya 51, BiyskayaOzimaya, Filatovka, Kulundinka, Poema (Russia) were characterized by high resistance to damping off (5.0 points).

Correlation-regression analysis confirmed that winter hardiness of soft winter wheat in the forest-steppe conditions of the Middle Volga region is one of the key indicators. In all the years of studies, strong and moderate positive relationships between the yield of varieties of soft winter wheat and their winter hardiness were established $\left(2011-r=0.69 \pm 0.08,2012\left(1^{\text {st }}\right.\right.$ set $)-r$ $=0.60 \pm 0.09,2012\left(2^{\text {nd }}\right.$ set $)-r=0.63 \pm 0.08,2013-r=$ $0.56 \pm 0.09$, all relationships are reliable at the significance level $0.1 \%$ ) (Fig. 1).

\section{Fig. 1. Correlation-regression relationship between soft winter wheat yield and winter hardiness}

Among cultivars with increased and high winter hardiness (4.0-5.0 points) in the first set, the yield was formed at the level of the standard variety Volzhskaya $\mathrm{K}$ (average for 2011-2012 $499 \mathrm{~g} / \mathrm{m}^{2}$ ) or higher by 35-164 $\mathrm{g} / \mathrm{m}^{2}$ of wheat cultivars Dashenka, Lytavinka, Manzheliya, Kalyanova (Ukraine) (Table 2).

Of the wheat cultivars in the second set, high values of winter hardiness and yield during the study were shown by the varieties Victoria 95, BiyskayaOzimaya, Kulundinka, Poema (Russia). The aforementioned varieties formed a yield of $256-483 \mathrm{~g} / \mathrm{m}^{2}$ with a yield of $265 \mathrm{~g} / \mathrm{m}^{2}$ of the standard variety Volzhskaya $\mathrm{K}$ on average for the years of studies in 2012, 2013.Plant height is an important characteristic of the soft winter wheat variety.

According to the classification proposed by V.F. Dorofeyev (1986), using the height of plants, the following groups of wheat are distinguished when growing in optimal agroclimatic conditions: tall (over $120 \mathrm{~cm})$, medium-sized (120-106 cm), short-stalked $(105-86 \mathrm{~cm})$, semi-dwarf $(85-61 \mathrm{~cm})$, dwarf $(60-41 \mathrm{~cm})$ and super dwarf (up to $40 \mathrm{~cm}$ ) [12].

In 2011, the height of the standard variety Volzhskaya K was $104 \mathrm{~cm}$. At the same time, the height of wheat varieties from Germany, Hungary, Bulgaria, Serbia, Ukraine and China varied from 34 to $94 \mathrm{~cm}$ with an average value of $72 \mathrm{~cm}$ in the experiment (Table 2). In the dry year of 2012, in the same set of wheats, the height of plants varied from 30 to $59 \mathrm{~cm}$, with the height of the standard wheat and the average value in the experiment being 71 and $49 \mathrm{~cm}$, respectively. Among the wheat varieties of the second set in 2012, wheat varieties originating from the Siberian region of Russia Bagrationovskaya, Novosibirskaya 32, Novosibirskaya 
51, Novosibirskaya 40, Filatovka, Kulundinka, BiyskayaOzimaya, were characterized by a relative tallness (79-98 cm). In 2013, the height of their plants was $86-104 \mathrm{~cm}$ in comparison with the standard variety Volzhskaya K of $72 \mathrm{~cm}$ and the average value in the experiment of $66 \mathrm{~cm}$. Only the variety Novosibirskaya 9 with a plant height of $60-62 \mathrm{~cm}$ can be referred to semi- dwarf Siberian wheats. Some varieties of the wheat collection set - Victoria 95 (Russia), Krassen (Ukraine), Orienta (USA) and Kitami 46 (Japan) - in 2013 also exceeded the standard wheat in plant height by $6-9 \mathrm{~cm}$. the super dwarf wheat group included Cameo (Russia), Ninka (Ukraine), Ji Mai 18 (China), Kitami 35 (Japan).

Table 2. Economic and biological indicators of highly productive varieties of soft winter wheat

\begin{tabular}{|c|c|c|c|c|c|c|c|}
\hline \multirow[t]{2}{*}{ Cultivars } & \multirow[t]{2}{*}{ Country } & \multicolumn{2}{|c|}{ Yield, $\mathrm{g} / \mathrm{m}^{2}$} & \multirow{2}{*}{$\begin{array}{c}\text { Winter } \\
\text { hardiness, } \\
\text { point }\end{array}$} & \multirow{2}{*}{$\begin{array}{l}\text { Height, } \\
\mathrm{cm}\end{array}$} & \multirow{2}{*}{$\begin{array}{c}\text { Ear } \\
\text { formation } \\
\text { date }\end{array}$} & \multirow{2}{*}{$\begin{array}{l}\text { Resistance to the } \\
\text { frit fly, point* }\end{array}$} \\
\hline & & average & $\begin{array}{l}+/ \text {-relative to } \\
\text { the standard }\end{array}$ & & & & \\
\hline \multicolumn{8}{|c|}{ First set (average for 2011-2012) } \\
\hline \multicolumn{2}{|c|}{ Volzhskaya K, standard } & 499 & - & 4.8 & 88 & $4 \mathrm{VI}$ & 3 \\
\hline Zamozhnist & Ukraine & 561 & +62 & 4.0 & 65 & $3 \mathrm{VI}$ & 3 \\
\hline Lytavinka & Ukraine & 467 & -32 & 4.5 & 65 & $1 \mathrm{VI}$ & 5 \\
\hline Manzheliya & Ukraine & 484 & -15 & 4.8 & 66 & $4 \mathrm{VI}$ & 3 \\
\hline Dashenka & Ukraine & 534 & +35 & 4.0 & 74 & $31 \mathrm{~V}$ & 1 \\
\hline Kalyanova & Ukraine & 663 & +164 & 4.5 & 70 & $1 \mathrm{VI}$ & 1 \\
\hline \multicolumn{2}{|c|}{ Average in the experiment } & 275 & -224 & 3.3 & 61 & $1 \mathrm{VI}$ & 3 \\
\hline \multicolumn{8}{|c|}{ Second set (average for 2012-2013) } \\
\hline \multicolumn{2}{|c|}{ Volzhskaya K, standard } & 265 & & 5.0 & 72 & $3 \mathrm{VI}$ & 3 \\
\hline Victoria 95 & Russia & 483 & +222 & 4.5 & 73 & $1 \mathrm{VI}$ & 3 \\
\hline Donskayalira & Russia & 256 & -9 & 4.0 & 46 & $29 \mathrm{~V}$ & 3 \\
\hline Poema & Russia & 378 & +113 & 5.0 & 75 & $2 \mathrm{VI}$ & 9 \\
\hline Filatovka & Russia & 280 & +15 & 5.0 & 101 & $4 \mathrm{VI}$ & 1 \\
\hline Kulundinka & Russia & 258 & -7 & 5.0 & 96 & $3 \mathrm{VI}$ & 1 \\
\hline BiyskayaOzimaya & Russia & 354 & +89 & 5.0 & 96 & $2 \mathrm{VI}$ & 3 \\
\hline Yasnogorka & Ukraine & 316 & +51 & 4.0 & 56 & $4 \mathrm{VI}$ & 7 \\
\hline \multicolumn{2}{|c|}{ Average in the experiment } & 183 & -82 & 3.5 & 62 & $1 \mathrm{VI}$ & 3 \\
\hline
\end{tabular}

$$
*-2012
$$

The height of plants of a variety of soft winter wheat is not only a criterion for its morphotype, but also have influence on many important economic and biological indicators.

Correlation-regression analysis established a positive relationship between the winter hardiness of soft winter wheat cultivars and the height of their plants. Correlation coefficients in 2011,2012 and 2013 were $0.57 \pm 0.12$ (reliable at the significance level of $0.1 \%$ ), $0.35 \pm 0.13$, $0.38 \pm 0.13(1,2$ sets, reliable at the significance level of $5 \%$ ) and $0.72 \pm 0.11$ (reliable at the significance level of $0.1 \%$ ), respectively (Fig. 2).

Increased and high winter hardiness (4.0-5.0 points) was combined with the short stalk rate (height up to 85 $\mathrm{cm})$ among wheat cultivars of the $1^{\text {st }}$ set - Myropol, Mykolayivka, Lytavinka, Vinnychanka, KhersonskaBezostaya, Manzhelija (Ukraine), Banga (Latvia), Emoile (Bulgaria), Xiao Yan 7, Zhong Pin 1535 (China), as well as the $2^{\text {nd }}$ set - Victoria 95, Cameo, Novosibirskaya 9, Lutescens 4, Poem (Russia), Krasen (Ukraine). In contrasting humidity conditions of the environment in the absence of lodging, change in the increase in the yield of winter wheat varieties with an increase in plant height was marked (Fig. 3). The correlation coefficients between the height of plants of soft winter wheat varieties and their yield were: in 2011 - 0.58 \pm 0.12 (direct relationship, average strength, reliable at the significance level of $0.1 \%$ ); in $2012-$ $0.53 \pm 0.12$ ( $1^{\text {st }}$ set, direct relationship, medium strength, reliable at the significance level of $0.1 \%$ ) and $0.31 \pm 0.14$ $\left(2^{\text {nd }}\right.$ set, direct relationship, medium strength, reliable at the significance level of 5\%); in $2013-0.34 \pm 0.14$ (direct relationship, medium strength, reliable at the significance level of 5\%) (Fig. 3).

The established positive correlations are not absolute. This means that among short-stalked wheat varieties there can be varieties with high yields, and among tall ones, on the contrary, with low yields [13]. A high yield of short-stalked wheat varieties can be achieved, for example, due to good foliage, a long-lasting photosynthetic apparatus of plants, and a strong attracting ability during the period of grain filling. And vice versa, tall genotypes, having a good assimilating surface, can be characterized by weak attraction in the last growing season and, as a consequence, a low yield.

Dwarf wheat varieties Donskaya Lira (Russia) with a plant height of 45-46 $\mathrm{cm}$ and Yasnogorka (Ukraine), with a plant height of $53-58 \mathrm{~cm}$, gave a yield of 256 $\mathrm{g} / \mathrm{m}^{2}$ and $316 \mathrm{~g} / \mathrm{m}^{2}$, respectively, with a yield of the standard variety Volzhskaya $\mathrm{K}$ of $265 \mathrm{~g} / \mathrm{m}^{2}$ and the average yield value in the experiment of $183 \mathrm{~g} / \mathrm{m}^{2}$ (Table 2 ). They are of interest both for production use, and as the source material for breeding soft winter wheat for a combination of short stalk and high productivity. 


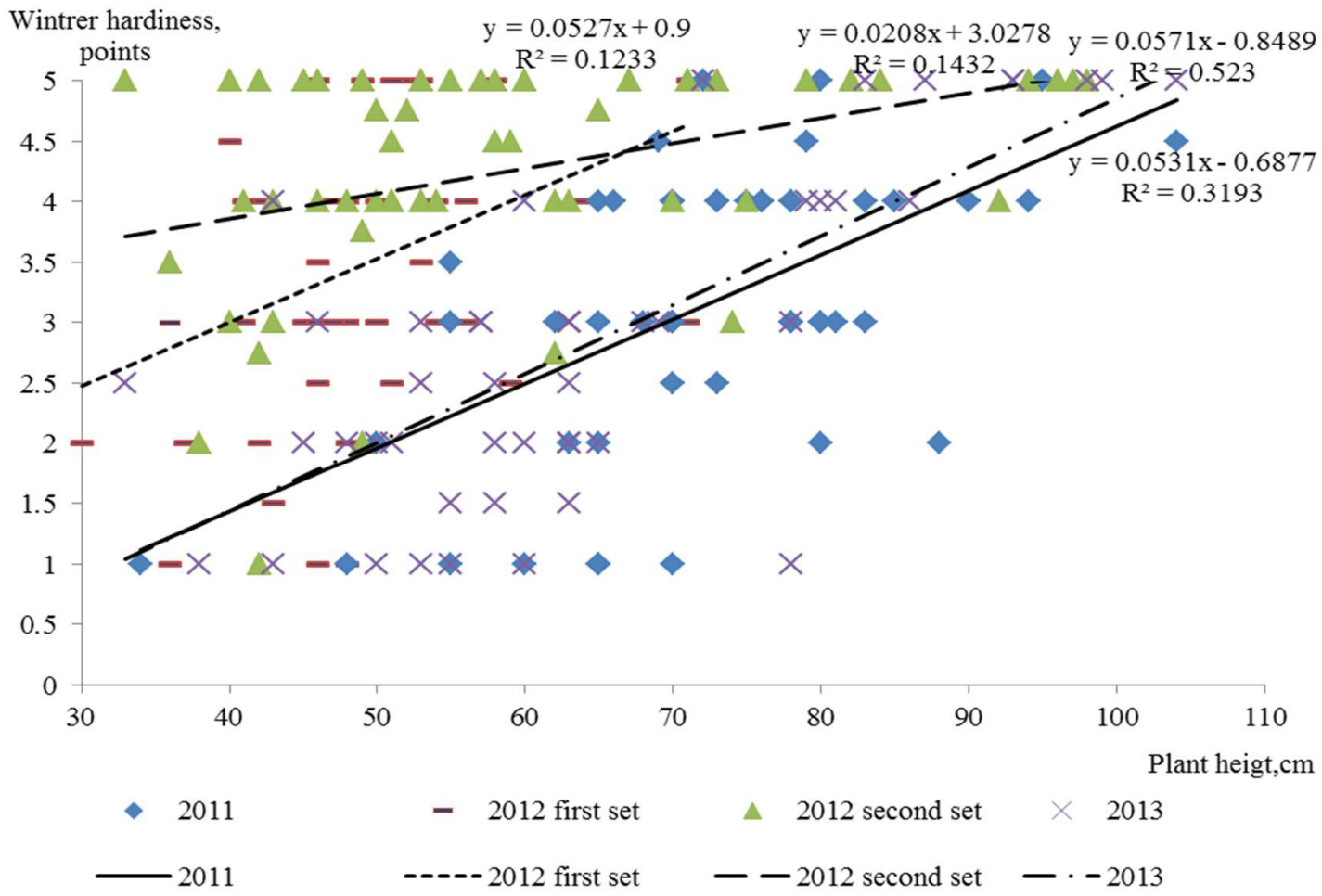

Fig. 2. Correlation-regression relationship between winter hardiness of soft winter wheat cultivars and plant height

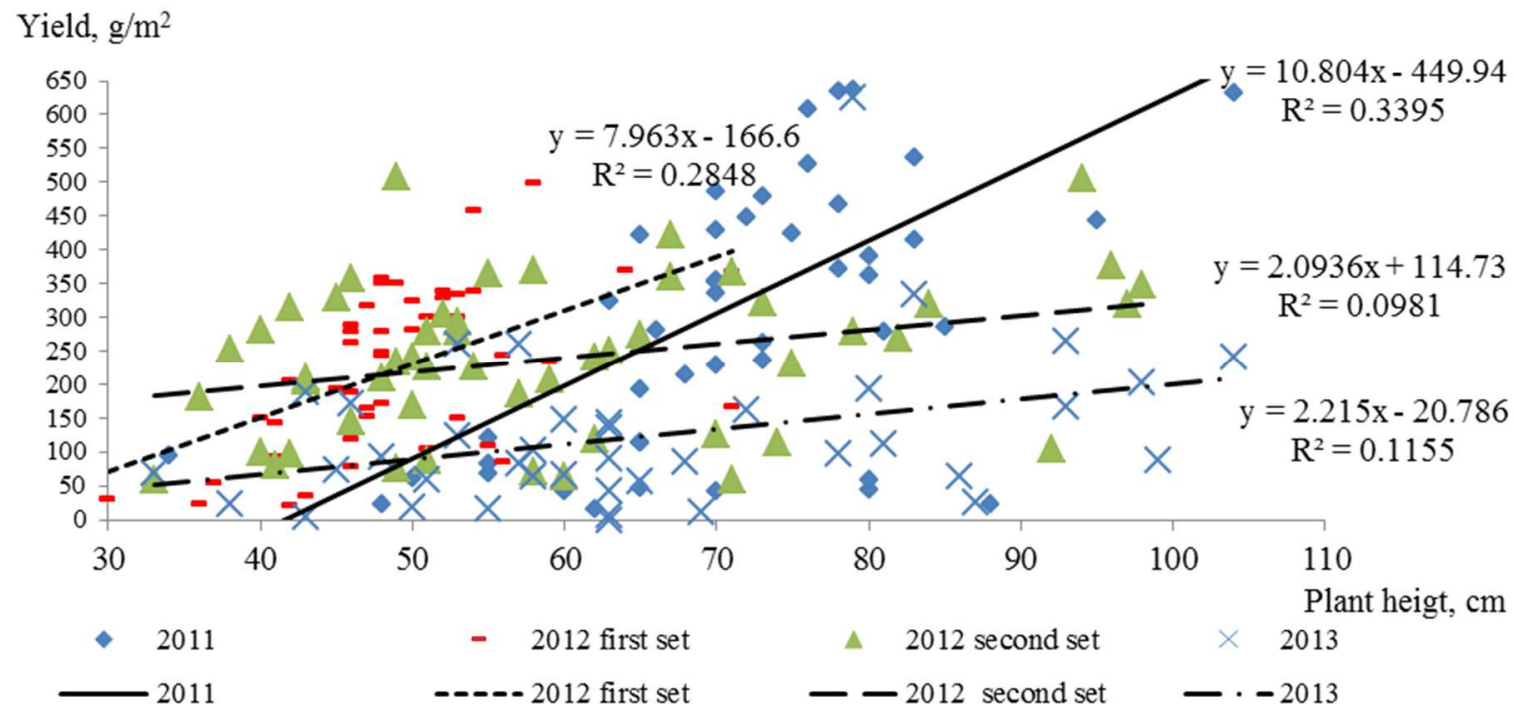

Fig. 3. Correlation-regression relationship between the yield of soft winter wheat cultivars and plant height

The duration of the growing season is an important biological, adaptive and economically valuable property of a plant variety of any crop $[14,15]$. In wheat breeding, the ear formation date is usually used to assess the ripeness group of a variety or a selection sample. The interphase period of sprouting - the ear formation in comparison with the period of sprouting-maturation is less variable, which makes it possible to consider the ear formation phase as a reliable criterion to determine the growing season of winter wheat varieties.

According to the scale of the International Classifier (1984), different groups of wheat ripeness are distinguished: medium early, early, very early, medium late, late, very late, with the ear formation of $2-3,4-5,6$ and more days earlier or later than the mid-ripening standard variety. Wheats that form the ear simultaneously with the standard variety or 1 day earlier or later belong to the mid-ripening group [16].

Among the studied range of wheats of the world collection in the forest-steppe conditions of the Middle Volga region, German varieties were characterized by late maturity, with the ear formation of 6-8 days later than the standard one. Ukrainian varieties were represented by wheats of different ripeness groups. 
Wheats from China, Japan, Bulgaria and the North Caucasus region of Russia were characterized by early maturity and mid-maturity. Wheats of the Siberian region of Russia came into ear at the level of the midseason standard variety (Table 1).

The varieties Victoria 95, Avesta (Russia), Vdachna, Shestopalivka, Myropol, Dukanka (Ukraine), Svilena, Emoile (Bulgaria), KS 8010-72, KS 96 WGRC 37, KS 96 WGRC 40, Pacer (USA), Kitami 46 (Japan) XiaoYan 6, Ji Mai 18, Ji Mai 30, Ji Mai 31, Ji Mai 36, Zhong Pin 1535 (China) were characterized by the early ear formation (by 2-11 days in comparison to the standard variety).

The late-ripening group of wheats included Akter and Compliment (Germany), in which the ear formation occurred 5-8 days later than the standard variety Volzhskaya K.

The varieties Dashenka, Kalyanova, Lytavinka (Ukraine), Victoria 95, Donskaya Lira (Russia) were characterized by early maturity (the ear formation 2-8 days earlier than the standard variety) and yield at the standard level $\left(630,367 \mathrm{~g} / \mathrm{m}^{2}\right.$ and $162 \mathrm{~g} / \mathrm{m}^{2}$ in 2011 , 2012 and 2013, respectively) or higher. In the group of mid-ripening wheats, the Manzhelija variety (Ukraine) in the studies of 2011, 2012 formed the yield at the level of the standard variety Volzhskaya K with $635 \mathrm{~g} / \mathrm{m}^{2}$ and $333 \mathrm{~g} / \mathrm{m}^{2}$, respectively. Wheats of the middle-late and late-ripening groups were inferior to the standard wheat in yield.

The cultivars Donskaya 50, Dominanta, Poema (Russia), Yasnogorka (Ukraine), Orienta, KS 96 WGRC34, KS 96 WGRC40 (USA), Xiao Yan 7, Zhong Pin 1507, Zhong Pin 1535 (China), Kitami 35 (Japan) were characterized by higher resistance (7-9 points) to the frit fly (Oscinella frit L.).

\section{Conclusion}

In the conditions of the forest-steppe of the Middle Volga region, 102 samples of soft winter wheat of various ecological and geographical origin from the collection of the All-Russian Institute of Plant Genetic Resources were studied; the sources of some economically valuable indicators were identified for use in breeding practice:

- high winter resistant - Omskaya 6, Bagrationovskaya, Novosibirskaya 32, Novosibirskaya 51, BiyskayaOzimaya, Filatovka, Kulundinka, Poema (Russia), Banga (Latvia), Emoile (Bulgaria), Myropol, Mykolayvka, Dashenka, Kalyanova, Lytavinka, Vinnychanka, Manzheliya, Khersonskabezostaya (Ukraine), Xiao Yan 107, Zhong Pin 1535 (China).

- highly productive - Victoria 95, Poema, BiyskayaOzimaya (Russia), Zamozhnist, Kalyanova, Yasnogorka (Ukraine) and others.

- early ripening - Vdachna, Shestopalivka, Myropol (Ukraine), Svilena, Emoile (Bulgaria), KS 96 WGRC 37, KS 96 WGRC 40, Pacer (USA), Kitami 46 (Japan) XiaoYan 6, Ji Mai 30, Ji Mai 36 (China) and others.

- short-stalked - Cameo (Russia), Ninka (Ukraine), Ji Mai 18 (China), Kitami 35 (Japan) and others.
- resistant to the frit fly - Donskaya 50, Dominanta, Poema (Russia), Yasnogorka (Ukraine), Orienta, KS 96 WGRC34, KS 96 WGRC40 (USA), Xiao Yan 7, Zhong Pin 1507, Zhong Pin 1535 (China), Kitami 35 (Japan).

\section{References}

1. N.N. Zakharova, N.G. Zakharov, M.N. Garanin, Bulletin of the Ulyanovsk State Agricultural Academy, 2 (2017).

2. G.Ya. Maslova, M.R. Abdryaev, I.I. Sharapov, Yu.A. Sharapova, Bulletin of Samara Scientific Center of the Russian Academy of Sciences, 20, 2, 4 (2018).

3. N.I. Vavilov, Scientific bases of wheat breeding (Selkhozgiz, Moscow; Leningrad, 1935).

4. A.F. Merezhko, Identified plant gene pool and breeding (AIPGR, St. Petersburg, 2005).

5. O.P. Mitrofanova, Vavilovsky journal of genetics and breeding, 16, 1 (2012).

6. State methods of crop variety testing; The second issue: grain crops, cereals, leguminous, corn and fodder crops (Moscow, 1989).

7. Guidelines for the study of the world wheat collection. 3rd ed., revised (AIPGR, Leningrad, 1977).

8. A.P. Samofalov, S.V. Podgorny, Agrarian Bulletin of the Urals, 5, 123 (2014).

9. M.A.J. Parry, P.J. Andralojc, M. Reynolds, M.E. Salvucci, C. Raines, X.-G. Zhu, G.D. Price, A.G. Condon, R.T. Furbank, Journal of Experimental Botany, 62, 2 (2011).

10. N.V. Tupitsyn, V.N. Tupitsyn, Bulletin of the Russian Academy of Agricultural Sciences, 2 (2012).

11. N.N. Zakharova, N.G. Zakharov, Bulletin of Ulyanovsk State Agricultural Academy, 3, 47 (2019).

12. V.F. Dorofeyeva (ed.), Wheats of the World: Species Composition, Breeding Achievements, Modern Problems and Initial Material (Agropromizdat, Leningrad department, 1987).

13. N.V. Tupitsyn, Bulletin of the Russian Academy of Agricultural Sciences, 1 (2019).

14. G.A. García, R.A. Serrago, D.J. Miralles, L.A. Lombardo, M.L. Appendino, L.S. Vanzetti, M. Helguera, Field Crops Research, 124, 3 (2011).

15. G.D. Nabokov, Wheat and triticale: Materials of the scientific conference "Green Revolution of P.P. Lukyanenko” (Krasnodar, 2001).

16. International Classifier CMEA of the genus Triticum (L., 1984). 